\title{
ON THE TRANSGLYCOSIDATION RELATING TO RIBOFLAVIN BY ESCHERICHIA COLI
}

\section{FORMATION OF RIBOFLAVINYL GLUCOSIDE}

\author{
HIDEO KATAGIRI, HIDEAKI YAMADA AND KAZUTAMI IMAI
}

Department of Agriculture, Kyoto University, Sakyo, Kyoto

(Received September 10, 1957)

Recently it has been found (1) in our laboratory that $\mathrm{B}_{2}{ }^{1}$ and $\mathrm{B}_{2} \mathrm{G}^{1}$ play important roles of transglucosidation as revealed by a mutant strain of Aspergillus oryzae. Not only $\mathrm{B}_{2} \mathrm{G}$, but also a series of riboflavinyl glycosides, e.g., riboflavinyl-galactoside, -fructoside, -oligosaccharides, and several new flavinyi phosphates, have been isolated in our laboratory from Asp. oryzae (2-5) as well as Escherichia coli. Thus new transferring reactions of sugar relating to $\mathrm{B}_{2}$ have been assumed by the authors to be one of the synthetic processes of $(1 \rightarrow 6)$ type polysaccharides occurring in bacteria.

In the present paper largely the experiments on $\mathrm{B}_{2} \mathrm{G}$ will be described, i.e., the isolation of crystalline $\mathrm{B}_{2} \mathrm{G}$ synthesized by dried cells of $E$. coli, the comparison of the crystals of this glucoside with those obtained from rat liver (6) or Asp. oryzae (2), and the conditions on the formation of $\mathrm{B}_{2} \mathrm{G}$ by the bacterial enzyme.

\section{EXPERIMENTAL}

\section{Materials and Methods}

Materials $-\mathrm{B}_{2}$ keto acid, i.e., 1, 2-dihydro-6,7-dimethy1-2-keto-1-D-ribity1-3quinoxaline carboxylic acid was synthesized by Surrey's method (7). Lumiflavin was prepared from $B_{2}$ by alkaline photolysis, and recrystallized repeatedly from ethanol until $B_{2}$ was no more detectable by paper chromatography. Ribityl lumazine, i.e., 8-N-ribityl-6,7-dimethyl-lumazine was kindly supplied from the Reseach Laboratory of Takeda Co. Ltd. Flavin mononucleotide (FMN) was a commercial product.

Organism - The organism used for this experiment was Escherichia coli neapolitanus (B-25). The bacterium was grown in a static culture at $37^{\circ}$ in a medium containing 1 per cent peptone, 1 per cent meat extract and 0.5 per cent $\mathrm{NaCl}$. The cells were harvested by Sharples centrifuge, and washed with distilled water. The thin layer of bacterial cells on a Petri dish was dried by an electric fan at room temperature, and kept the dried cells in a dessicator over $\mathrm{CaCl}_{2}$ under reduced pressure. For the experiments for isolating $\mathrm{B}_{2} \mathrm{G}$, the

\footnotetext{
1 The following abbreviations are used: riboflavin, $B_{2}$; riboflavinyl glucoside, $B_{2} G$.
} 
dried cells were used.

Preparation of Crude Enzyme- $1 \mathrm{~g}$ of the dried cells was ground in a porcelain mortar with $5 \mathrm{~g}$ of pyrex glass powder and $5 \mathrm{ml}$ of distilled water to a homogeneous paste, and then diluted to $40 \mathrm{ml}$ with water. The suspension was kept for half an hour at $30^{\circ}$, and the supernatant was collected by centrifugation. After being adjusted to $\mathrm{pH} 7.0$, the supernatant was dialysed overnight against $1 l$ of distilled water. The dialysed solution thus obtained was used for the investigations on the synthesis of $\mathrm{B}_{2} \mathrm{G}$.

Assay method The total volume of $5 \mathrm{ml}$ of the reaction mixture containing $2 \mathrm{ml}$ of the enzyme, $45 \mathrm{mg}$ of maltose $\left(2.5 \times 10^{-2} \mathrm{M}\right), 190 \boldsymbol{r}$ of $\mathrm{B}_{2}\left(1 \times 10^{-4} \mathrm{M}\right)$ and $1 \mathrm{ml}$ of glycine buffer $\left(1 \times 10^{-1} M\right)$, was adjusted to the requisite $\mathrm{pH}$ with $0.2 \mathrm{~N} \mathrm{HCl}$ or $\mathrm{KOH}$, and was kept in the dark at $30^{\circ}$.

Microdeterminaion of $\mathrm{B}_{2} \mathrm{G}$ was carried out principally by the method of Whitby (8) ; after the precipitate of enzyme protein was separated by centrifugation, flavin compounds in the supernatant were extracted with $0.25 \mathrm{ml}$ of phenol solution. From the phenol layer, $0.1 \mathrm{ml}$ was applied on the filter paper (Toyo, No. 51) $5 \mathrm{~cm}$ in length and developed with an ascending method for about 15 hours with a solvent system of butanol-pyridine-water $(6: 4: 3$, by volume). The chromatogram was dried, examined by ultraviolet lamp and the spot corresponding to $B_{2} G\left(R_{F}\right.$ 0.30) was marked.

The spot of $\mathrm{B}_{2} \mathrm{G}$ was cut, immerced in $5 \mathrm{ml}$ of distilled water and extracted by heating in a glass-stoppered tube for 15 minutes in the dark at $80^{\circ}$. The solution was cooled and filtered. $B_{2} G$ in the filtrate was then determined by measuring the optical density at $450 \mathrm{~m} /$ with spectrophotometer. Control experiment using standard $\mathrm{B}_{2}$ solution showed that the result was satisfactory for quantitative determination.

\section{Results}

Isolation of $B_{2} G$ Synthesized by Dried Cells-- $100 \mathrm{ml}$ of the incubation mixture containing $2 \mathrm{~g}$ of maltose, $40 \mathrm{mg}$ of $\mathrm{B}_{2}, 60 \mathrm{mg}$ of flavin mononucleotide $(\mathrm{FMN})^{2}, 40 \mathrm{ml}$ of glycine buffer $(\mathrm{pH} 7.0)$ and $1 \mathrm{~g}$ of dried cells suspended in distilled water, was incubated at $30^{\circ}$ in the dark for 24 hours, followed by Crammer's procedure (9), and all the flavin compounds were finally extracted with $10 \mathrm{ml}$ of distilled water.

In this extract, 3 or 4 new $B_{2}$ compounds migrating to the cathode in paper electrophoresis according to Siliprandi (10), were observed as shown in Fig. 1. The isolation of $\mathrm{B}_{2} \mathrm{G}$ was instituted with paper chromatography on a macroscale, by developing at first with water saturated with isoamyl alcohol and then with butanol-pyridine-water $(6: 4: 3)$, as described above.

The bands of $\mathrm{B}_{2} \mathrm{G}$ on the paper chromatograms were eluted with distilled water by a descending method. The eluate was evaporated to dryness at $45^{\circ}$ under reduced pressure, and dissolved in $5 \mathrm{ml}$ of water. The insoluble impurities were removed by centrifugation.

The supernatant was reduced by adding hydrosulfite at $0^{\circ}$, as described by

2. FMN was rapidly decomposed into inorganic phosphate and $B_{2}$ by the phosphatase of $E$. coli, and the liberated $\mathrm{B}_{2}$ was then utilized as glycosyl acceptor in the reaction system. 


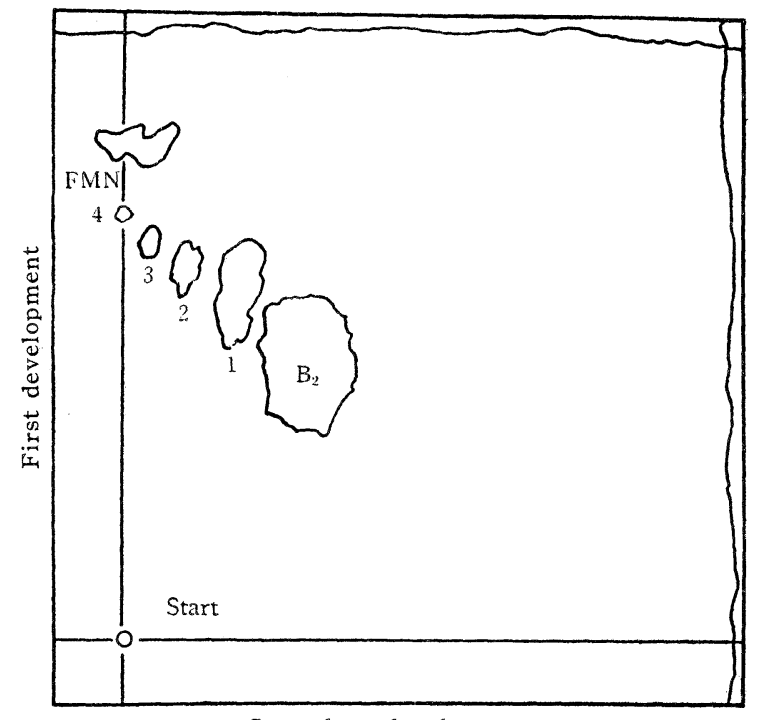

Secondary development

Fra. 1 Two-Dimensional Paper Chromatogram of the Reaction Products from $B_{2}$ and Maltose by Dried Cells of E. coli.

Reaction mixture containing $\mathrm{B}_{2}, \mathrm{FMN}$, maltose and dried cells in glycine buffer $(\mathrm{pH} 7.0)$ was incubated at $30^{\circ}$ for $24 \mathrm{hr}$. Each spot was detected under ultraviolet lamp. Spot 1 corresponds to $B_{2} G$, and spots 2,3 and 4 to $B_{2}$ compounds of oligosaccharide. Chromatogram was developed at first with water saturated with isoamyl alcohol, followed by developing with propanol-0.1 $\mathrm{N} \mathrm{NH}_{4} \mathrm{OH}(3: 1)$.
Masuda (11) for the purification of flavin adenine dinucleotide. The precipitate of reduced $\mathrm{B}_{2} \mathrm{G}$ which was collected by centrifugation and washed with a small amount of distilled water, was suspended in $5 \mathrm{ml}$ of distilled water, and then aerated until it was dissolved in the oxidized form. The insoluble residue was removed and the supernatant was concentrated to $2 \mathrm{ml}$ under reduced pressure at $45^{\circ}$.

After several recrystallizations from ethanol at $-5^{\circ}$, about $2 \mathrm{mg}$ of orange crystalline powder was obtained. The ratio of optical densities, $375 \mathrm{~m} \mu / 450 \mathrm{~m} \mu$, was found to be 0.86 , and the nitrogen content of this crystal corresponded to 93 per cent of the theoretical value.

Moreover, this preparation was found to be identical with the $\mathrm{B}_{2} \mathrm{G}$ preparations obtained with rat liver and with Asp. oryzae in the characteristics of

TABLE I

Chemical Properties of $B_{2} G$

\begin{tabular}{|c|c|c|c|}
\hline Source of enzyme & $E \cdot \operatorname{coli}^{a}$ & Rat liver & Asp. oryzae \\
\hline $\mathrm{B}: \mathrm{Ac}: \mathrm{W}$ & 0.20 & 0.20 & 0.21 \\
\hline $\mathrm{P}: \mathrm{W}$ & 0.40 & 0.40 & 0.40 \\
\hline W : iso Amyl & 0.51 & 0.50 & 0.50 \\
\hline Ratio of $(260 \mathrm{~m} \mu / 450 \mathrm{~m} \mu$ & 2.24 & 2.25 & 2.24 \\
\hline $275 \mathrm{~m} \mu / 450 \mathrm{~m} \mu$ & 2.03 & 2.03 & 2.03 \\
\hline $375 \mathrm{~m} \mu / 450 \mathrm{~m} \mu$ & 0.86 & 0.85 & 0.86 \\
\hline$\frac{\mathrm{mp}{ }^{\circ} \mathrm{C}}{\text { (with decomposition) }}$ & 250 & $247-248$ & $249-250$ \\
\hline
\end{tabular}

${ }^{a}$ The values obtained in the present experiments

$R_{\mathrm{F}}$ values were observed with Toyo filter paper No. 2 using following solvent systems :

B:Ac:W, Butanol-acetic acid-water $(4: 1: 5) ; \mathrm{P}: \mathrm{W}, \mathrm{Na}_{2} \mathrm{HPO}_{4} \cdot 12 \mathrm{H}_{2} \mathrm{O}$-water $(5: 100) ; \mathrm{W}: i$ soAmyl, water saturated with $i$ soamyl alcohol. 
ultraviolet absorption spectra and the behaviours of paper chromatography (Table I). It was decomposed at about $250^{\circ}$ and turned brown. Glucose was confirmed by paper chromatography of the hydrolysate obtained by heating with $2 \mathrm{~N} \mathrm{HCl}$ at $100^{\circ}$ for 2 hours.

Fundamental Conditions for Synthesis of $B_{2} G$ The rate of synthesis of $\mathrm{B}_{2} \mathrm{G}$ with the enzyme of $E$. coli was at first linear during 12 hours, and then increased gradually until 20 hours, when the reaction reached to an equilibrium state (Fig. 2). On this state, a secondary reaction in which synthesized $\mathrm{B}_{2} \mathrm{G}$ acts as an acceptor

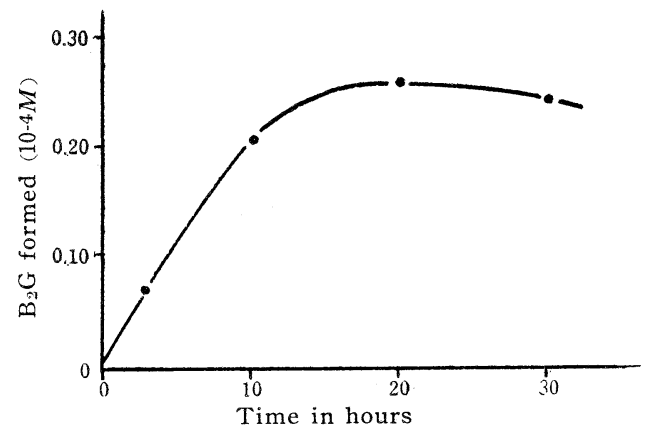

Fit. 2 Formation of $B_{2} G$ from Maltose and $B_{2}$ by the Enzyme of $E$. coli

Reaction mixture (total volume $50 \mathrm{ml}$ ) containing $2.5 \times 10^{-2} \mathrm{M}$ maltose, $1 \times 10^{-4} \mathrm{M}$ $\mathrm{B}_{2}, 0.1 M$ glycine buffer ( $\mathrm{pH} 7.0$ ) and $2 \mathrm{ml}$ of enzyme, was incubated at $30^{\circ}$. of glucosyl, was proceeding. This problem will be discussed in the following paper.

(a)

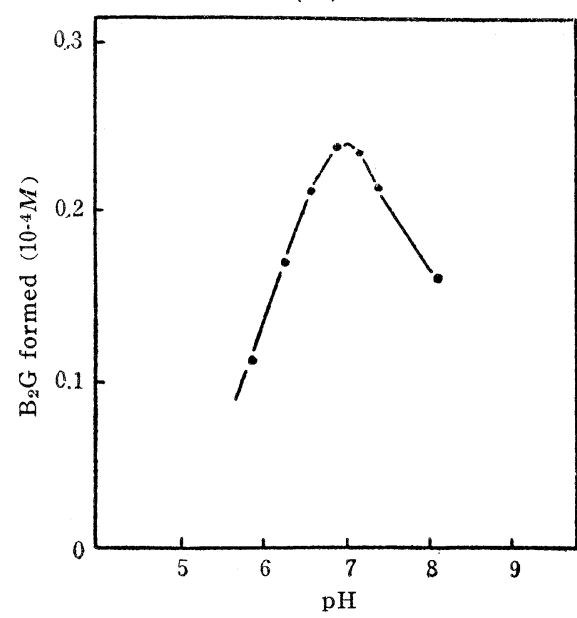

$(b)$

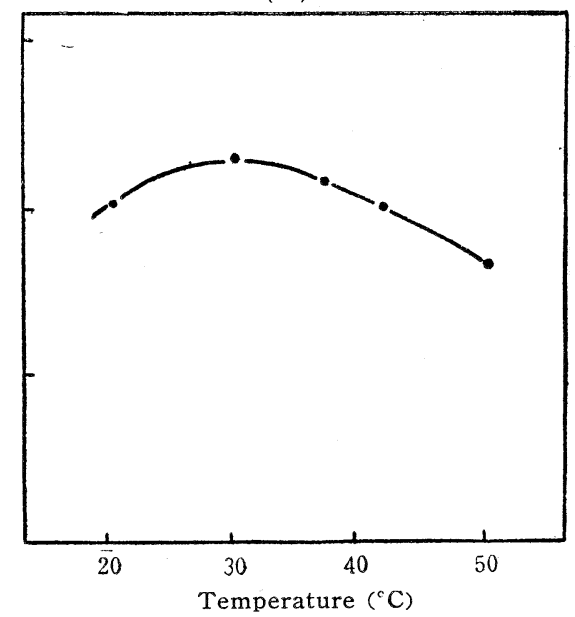

FIG. 3 Effect of $p H$ and Temperature on the Rate of $B_{2} G$ Formation

Reaction mixture (total volume $5 \mathrm{ml}$ ) containing $2.5 \times 10^{-2} \mathrm{M}$ maltose, $1 \times 10^{-4} \mathrm{M}$ $\mathrm{B}_{2}, 0.1 M$ glycine buffer and $2 \mathrm{ml}$ of enzyme was incubated for $20 \mathrm{hr}$.

pH optima were 6.8 to 7.0 (Fig. $3 a$ ), and at pH 6.9 (0.1 $M$ glycine buffer), the optimum temperature was about $30^{\circ}$ (Fig. $3 b$ ). With the glycine buffer higher yield of about 10 per cent than with equimolar citrate buffer was observed, and $2 \times 10^{-2} M$ phosphate buffer revealed inhibitory effect on the reaction system. The enzyme was found to be rapidly inactivated on $\mathrm{pH}$ below 5.0 at $0^{\circ}$, although it showed considerable stability on an alkaline side.

As for the glucosyl donor, experiments were carried out with various saccharides (Table II). Maltose was found to be the most suitable donor, whereas 
TABLE II

Synthesis of $B_{2} G$ from Various Saccharides

Reaction mixture (total volum $5 \mathrm{ml}$ ), containing $5 \times 10^{-2} \mathrm{M}$ saccharide, $1 \times 10^{-4}$ $M \mathrm{~B}_{2}, 0.1 M$ glycine buffer ( $\mathrm{pH} 7.0$ ) and enzyme, was kept at $30^{\circ}$ for $20 \mathrm{hr}$.

\begin{tabular}{ccc}
\hline Glucosyl-donating substances & $\mathrm{B}_{2} \mathrm{G}$ synthesized & Ratio of utility ${ }^{a}$ \\
& $m M$ & \\
Starch & 0 & 0 \\
Dextrin & 0.06 & 22 \\
Glycogen & 0.12 & 43 \\
Maltose & 0.28 & 100 \\
Sucrose & 0.08 & 29 \\
Trehalose & 0.13 & 47 \\
Glucose & 0.02 & 7 \\
Salicin & 0.02 & 7 \\
\hline
\end{tabular}

${ }^{a}$ Expressed as percentage of the action with maltose.

glucose was hardly utilized. Therefore, this type of transglucosidation is assumed to belong to the group transfer of $\mathrm{D}$-glucosyl group from maltose to $\mathrm{B}_{2}$.

Effect of Phosphates and Arsenate ... The synthesis of $\mathrm{B}_{2} \mathrm{G}$ was inhibited by inorganic phosphate and arsenate. By the addition of phosphate, maltose was partially decomposed phosphorolytically into glucose and glucose 1-phosphate which was comfirmed by paper chromatography of two-dimensional method (12). The inhibitory effect by glucose 1-phosphate, as reported by Whitby (8), was again observed in this experiment, and its inhibition was attributable to the competitive effect on glucosyl-donating substances. Glucose 6-phosphate was also inhibitory, but its degree of inhibition was fairly low. It is interesting to note that these inhibiting effects were almost abolished when $\mathrm{NaF}$ was added in the concentration of $0.1 M$ (Table III), as it has been known that $\mathrm{NaF}$ inhibits the formation of enzyme-phosphate complex.

TABLE III

Effect of Inorganic Phosphate, Arsenate, Sugar Phosphates and NaF on the Formation of $B_{2} G$

Reaction mixture (total vloume $5 \mathrm{ml}$ ), containing $\mathrm{B}_{2}$, maltose and enzyme in glycine buffer as described in Table II, was kept at $30^{\circ}$ for $20 \mathrm{hr}$.

\begin{tabular}{lcc} 
Addition & Concentration & Inhibition \\
Na-phosphate & $m M$ & per cent \\
Na-phosphate & 2 & 20 \\
Na-arsenate & 20 & 30 \\
Na-arsenate & 2 & 25 \\
Glucose 1-phosphate & 20 & 35 \\
", + NaF & 25 & 65 \\
Glucose 6-phosphate & $25 ; 100$ & 20 \\
" + NaF & 25 & 25 \\
\hline
\end{tabular}

Effect of Uridine Nucleotide - The synthesis of $\mathrm{B}_{2} \mathrm{G}$ was not affected by uridine nucleotide, which was prepared from yeast by the method of Caputto 
(13), although in the glycosyl-transferring systems of plants and some microorganisms $(14,15)$, uridine diphosphoglucose was suggested to play a specific role as an intermediate product (Table IV).

TABLE IV

Effect of Uridine Nucleotide on the Formation of $B_{2} G$

Experimental conditions were the same as in Table III.

\begin{tabular}{ccc} 
Addition & Concentration & $\begin{array}{c}\text { The amount of } \\
\mathrm{B}_{2} \mathrm{G} \text { formed }\end{array}$ \\
\hline Yeast nucleotide & $m M$ & $m \boldsymbol{M}$ \\
+ ATP & $2(\mathrm{mg})$ & 0.019 \\
Uridylic acid & $2(\mathrm{mg}) ; 0.2$ & 0.019 \\
$"+$ ATP & 1.0 & 0.018 \\
None & $1.0 ; 0.2$ & 0.018 \\
\end{tabular}

Acceptor Specificity - Whitby (8) already given attention to the changes in the degree of glucoside formation by rat liver enzyme according to different isoalloxazine derivatives.

The results of experiments (Table V) using $B_{2}$ analogues showed that the transferring reaction was quite specific to the kinds of $B_{2}$ analogues as an acceptor, i.e., $\mathrm{B}_{2}$ keto acid which was prepared from $B_{2}$ by removing pyrimidine part of isoalloxazine ring, failed to play any role as an acceptor, since the spots corresponding to the compound of $\mathrm{B}_{2}$ keto acid and glucose were not detected in paper chromatograms. For ribityl lumazine, which is lacking in the benzene part of isoalloxazine ring, a natural substance produced by mould was used. Any glucosyl compounds of ribityl lumazine were never detected, but ribityl lumazine was found to reveal an inhibitory effect on the synthesis of $\mathrm{B}_{2} \mathrm{G}$. Remarkable inhibition on $\mathrm{B}_{2} \mathrm{G}$ formation was observed with lumiflavin, as given in a Lineweaver-Burk plot (16) in Fig. 4, which shows competitive inhibition between $\mathrm{B}_{2}$ and lumiflavin.

It is suggested that $B_{2}$ as a

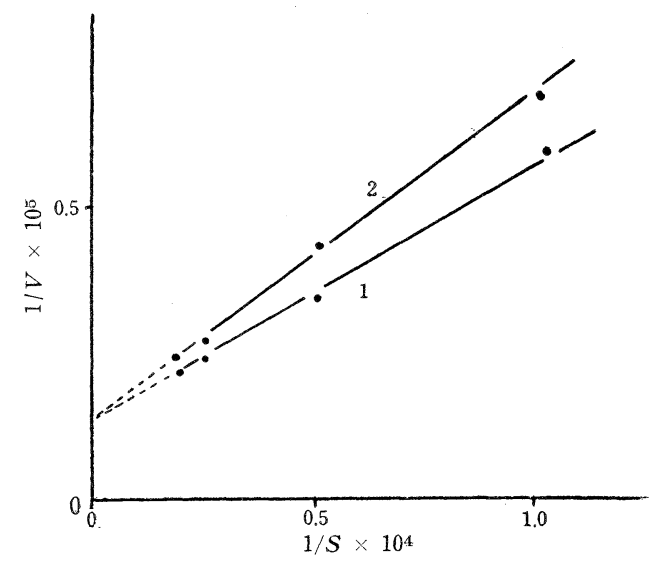

Frg. 4 Competitive Inhibition on the Synthesis of $\mathrm{B}_{2} G$ by Lumiflavin

Curve 1. without lumiflavin. Curve 2. with $1 \times 10^{-4} M$ lumiflavin. Ordinate $(1 / V)$ : reciprocal value of the amount of formation of $\mathrm{B}_{2} \mathrm{G}(1 / M / 2 \mathrm{ml}$ enz. $/ 20 \mathrm{hr})$. Abscissa $(1 / S)$ : reciprocal value of final concentration $(M)$ of $\mathrm{B}_{2}$.

Reaction mixture (total volume $5 \mathrm{ml}$ ) was incubated at $30^{\circ}$ for $20 \mathrm{hr}$ as was shown in Table III. 
TABLE V

Inhibitory Effect of $B_{2}$ Analogues on $B_{2} G$ Formation

Experimental conditions were the same as in Table III.

\begin{tabular}{lcc}
\multicolumn{1}{c}{ Addition } & Concentration & Inhibition \\
\hline & $m M$ & per cent \\
B keto acid & 0.2 & 13 \\
Ribityl lumazine & 0.2 & 36 \\
Xanthine & 0.4 & 36 \\
Uracil & 0.4 & 13 \\
Lumiflavin & 0.2 & 82 \\
\hline
\end{tabular}

glucosyl acceptor is activated by the enzyme, producing the $\mathrm{B}_{2}$-enzyme intermediate in the first step of this transglucosidation. Therefore phenol derivatives such as salicylic and $p$-aminosalicylic acids, which were assumed to inhibit the formation of this intermediate product (17), also revealed strong inhibitory effects on $\mathrm{B}_{2} \mathrm{G}$ formation (Table VI).

\section{TABLE VI}

Inhibitory Effect of Phenol Derivatives

Experimental conditions were the same as in Table III.

\begin{tabular}{ccc} 
Addition & Concentration & Inhibition \\
\hline & $m M$ & per cent \\
-Nitrophenol & 50 & 50 \\
Salicylic acid & 100 & 85 \\
$p$-Aminosalicylic acid & 100 & 55 \\
\hline
\end{tabular}

\section{TABLE VII}

Effect of Functional Group Reagents on the Activity of Enzyme

Experimental conditions were the same as in Table III. The reagents were added to the buffered enzyme solutions and kept for 15 minutes before the addition of substrates.

\begin{tabular}{|c|c|c|}
\hline Reagent & Concentration & Inhibition \\
\hline & $m M$ & per cent \\
\hline $\mathrm{KCN}$ & 5 & -9 \\
\hline$\alpha \alpha^{\prime}$-Dipyridyl & 1 & -5 \\
\hline EDTA & 1 & 9 \\
\hline PCMB & 0.1 & 77 \\
\hline, & 1 & 82 \\
\hline PCMB + Cysteine & $1 ; 10$ & 18 \\
\hline $\mathrm{PCMB}+\mathrm{GSH}$ & $1 ; 10$ & 14 \\
\hline $\mathrm{AgNO}_{3}$ & 1 & 100 \\
\hline $\mathrm{CuSO}_{4}$ & 1 & 73 \\
\hline $\mathrm{I}_{2}$ & 1 & 100 \\
\hline Cystine & 10 & 50 \\
\hline $\mathrm{K}_{3} \mathrm{Fe}(\mathrm{CN})_{6}$ & 1 & 50 \\
\hline $\mathrm{HgI}$ & 1 & 91 \\
\hline
\end{tabular}


Methanol, nitrophenol and sugar alcohol failed to act as direct acceptors of glucosyl to form methyl glucoside, etc. Moreover, no noticeable effect of these alcohols was observed on the formation of $\mathrm{B}_{2} \mathrm{G}$.

Effect of Functional Group Reagents The enzyme of $E$. coli lost its activity easily by oxidation. The effects of mild oxidizing reagents and $\mathrm{SH}$ reagents were examined, with the results shown in Table VII.

The enzyme activity was slightly increased by the addition of KCN or $\alpha, \alpha^{\prime}$-dipyridyl, and inhibited strongly by heavy metal ions even at low concentrations. The inhibition by $p$-chloro-mercuriben-

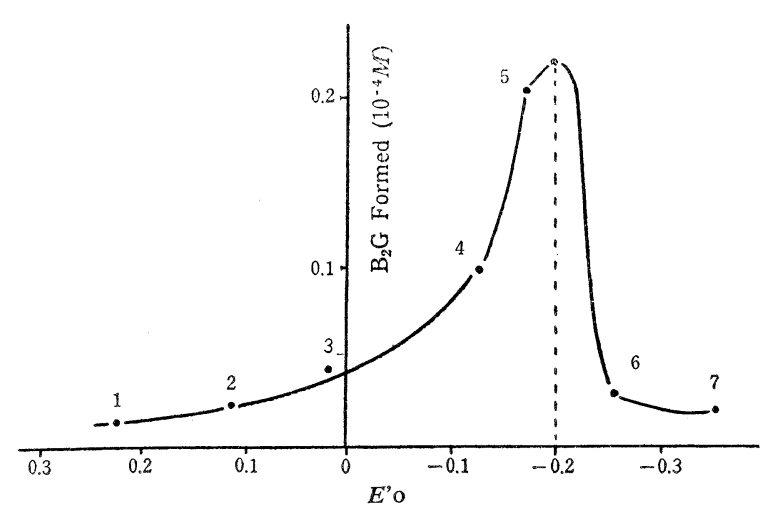

Fig. 5 Effect of Redox Dyes on the Formation of $\mathrm{B}_{2} G$

Reaction mixture (total volume $5 \mathrm{ml}$ ) containing maltose, $\mathrm{B}_{2}$ and enzyme in glycine buffer ( $\left.\mathrm{pH} 7.0\right)$ and 0.1 per cent of redox dyes represented below, was kept at $30^{\circ}$ for $20 \mathrm{hr}$.

No. 1, 2,6-dichlorophenol indophenol $\left(E_{0}=0.217\right)$; No. 2, toluylene blue $(0.115)$; No. 3, methylene blue $(0.001)$; No. 4, indigo disulfonate (-0.125); No. 5 , cresyl violet $(-0.163)$; No. 6 , phenosafranine $(-0.252)$; No. 7 , neutral red $(-0.340)$. zoate (PCMB) was almost complete at the concentration of $1 \times 10^{-4} M$, but it was reversed satisfactorily by the addition of cysteine or glutathione (GSH).

Effect of Redox Dyes - The relationship between the activity of the enzyme and the redox potential of the reaction mixture was shown in Fig. 5 . It will be seen that the maximum activity was observed at the potential -0.19 volt, which is identical to the normal potential of $B_{2}$ itself. From this result it is assumed that $B_{2}$ may play another role in keeping optimum redox potential for $\mathrm{B}_{2} \mathrm{G}$ formation.

\section{DISCUSSION}

The results of the above experiments on the suitable conditions of $B_{2} G$ formation, have led to the conclusion that the cause of the transferring action is attributable to the combination of isoalloxazine with an active site of an enzyme molecule, especially the combination of the pyrimidine part of isoalloxazine ring with the functional group of the enzyme protein, possibly through a hydrogen bond. It is also assumed that the $\mathrm{B}_{2}$-enzyme intermediate product thus formed may give rise to the transformation of glucosyl group under a suitable redox potential, whereas inorganic phosphate inhibits the formation of the intermediate product and phosphorolytical decomposition of sugar takes place. Namely, the mechanism of transglucosidation is not a direct combination of monosaccharide to $B_{2}$, but a transfer of glucosyl group from maltose to $B_{2}$ via an enzyme as postulated as follows. 


$$
\begin{aligned}
& \mathrm{B}_{2}+\mathrm{E} \rightleftharpoons \mathrm{B}_{2} \mathrm{E} \\
& \mathrm{B}_{2} \mathrm{E}+\text { maltose } \rightarrow\left(\mathrm{B}_{2} \mathrm{E}\right) \text { glucose }+ \text { glucose } \\
& \left(\mathrm{B}_{2} \mathrm{E}\right) \text { glucose } \rightleftharpoons \mathrm{B}_{2} \mathrm{G}+\mathrm{E}
\end{aligned}
$$

Where $\mathrm{E}$ represents the transferring enzyme, $\mathrm{B}_{2} \mathrm{E}$ the intermediate product, and $\left(\mathrm{B}_{2} \mathrm{E}\right)$ glucose the glucosidated intermediate.

This reaction, together with the finding which will be reported in the following papers, explains the continuous transglucosidation to increase the number of glucosyl groups in order to form $\mathrm{B}_{2}$ compounds of oligosaccharide. Thus this reaction gives a quite new interpretation of the action of $B_{2}$ under a suitable redox potential.

There have been many elaborate discussions about group-transferring actions. Recently it has been recognized that a large number of hydrase catalyzes group transfer among certain donors and acceptors other than water. However, there is no definite conclusion about the relationship between an acceptor and the corresponding enzyme.

The authors have pointed out already the transglucosidation by Asp. oryzae relating to $B_{2}$ in the previous report (1). These results also confirm the possible existence of $\mathrm{B}_{2}$-enzyme intermediate product.

\section{SUMMARY}

1. $\mathrm{B}_{2} \mathrm{G}$ synthesized from maltose and $\mathrm{B}_{2}$ by $E$. coli, compared with those obtained by the enzyme of rat liver and of Asp. oryzae. The chemical properties of these $B_{2} G$ are found to be quite identical.

2. For the formation of $\mathrm{B}_{2} \mathrm{G}$, the optimum temperature and $\mathrm{pH}$ were found to be $30^{\circ}$ and 6.9 , respectively, and maltose was chosen as most suitable glucosyl donor among various saccharides.

3. The formation of $B_{2} G$ was inhibited by both inorganic and organic phosphates, and the latter is attributed to the competitive effect on glucosyl-donating substances. Powerful inhibition revealed by the mild oxidizing reagents and $\mathrm{SH}$ reagents is due to the direct action on the enzyme itself.

4. The isoalloxazine ring of $B_{2}$ was found to play an important role in this kind of transglucosidation, and the glucosidation was inhibited profoundly by lumiflavin. The redox potential of $\mathrm{B}_{2}$ is suitable for the glucosidation. The authors have postulated the mechanism of this transglucosidation and discussed on its significant role.

\section{REFERENCES}

1. Katagiri, H., and Tachibana, S., Proc. 9th Symposium on Enzyme Chemistry (Japanese) 59 (1956).

2. Tachibana, S., and Katagiri, H., Vitamins 8, 304 (1955).

3. Tachibana, S., ibid. 9, 119 (1955); 9, 125 (1955).

4. Tachibana, S., and Katagiri, H., ibid. 8, 310 (1955).

5. Tachibana, S., ibid. 8, 356 (1955) ; 12, 217 (1957) ; 12, 223 (1957).

6. Whitby, L. G., Biochem. J. 50, 433 (1952). 
7. Surrey, A. R., and Nacliod, F. C., J. Am. Chem. Soc. 73, 2336 (1951).

8. Whitby, L. G., Biochem. J. 57, 390 (1954).

9. Crammer, J. L., Nature 161, 349 (1948).

10. Siliprandi, N., Siliprandi, D., and Lis, H., Biochim. Biophys. Acta 14, 212 (1954).

11. Masuda, T., Sawa, Y., Asai, M., and Kuwada, S., J. Vitaminol. 1, 185 (1955).

12. Bandurski, R. S., and Axelrod, B., J. Biol. Chem. 193, 405 (1951).

13. Caputto, R., Leloir, L. F., Cardini, C. E. and Paladini, A. C. ibid. 184, 333 (1950).

14. Leloir, L. F., and Cardini, C. E., J. Am. Chem. Soc. 756084 (1953).

15. Kalckar, H. M., Biochim. Biophys. Acta 12, 250 (1953).

16. Lineweaver, H., and Burk, D., J., Am. Chem. Soc. 56, 658 (1934).

17. Yagi, K., and Matsuoka, Y., Biochem. Z. 328, 138 (1956). 